\title{
Tindak Tutur Ilokusi dalam Sinetron Tukang Ojek Pengkolan di Stasiun Televisi RCTI
}

\author{
Pondra Muliawan ${ }^{1}$ \\ ${ }^{1}$ STIT Darul Ishlah Tulang Bawang, Indonesia \\ 1pondramuliawan93@gmail.com
}

\begin{abstract}
Abstrak
Penelitian ini bertujuan untuk mendeskripsikan tindak tutur ilokusi yang terdapat pada percakapan sinetron "Tukang Ojek Pengkolan" dan mengidentifikasi fungsi tuturan ilokusi yang terdapat dalam percakapan sinetron "Tukang Ojek Pengkolan". Jenis penelitian ini bersifat deskriptif dengan menggunakan metode kualitatif berdasarkan pendekatan prgmatik. Penelitian yang berjenis kualitatif ini memaparkan jenis tindak tutur ilokusi dan konteks tuturan dalam sinetron Tukang Ojek Pengkolan yang ditayangkan di stasiun televisi RCTI. Berdasarkan analisis, ditemukan adanya tindak tutur ilokusi yang terdiri dari empat jenis tindak tutur, yaitu tindak tutur representatif yang digunakan dalam konteks menyatakan, melaporkan, dan mengeluh. Tindak tutur ilokusi direktif digunakan dalam konteks menasihati memesan, dan memohon. Tindak tutur ilokusi komisif digunakan dalam konteks menawarkan. Tindak tutur ilokusi ekspresif digunakan dalam konteks mengucapkan terima kasih dan meminta maaf.
\end{abstract}

Kata Kunci: pragmatik, tindak tutur, llokusi, Tukang Ojek Pengkolan

\section{Pendahuluan}

Manusia adalah makhluk berpikir. Manusia mengucapkan pikirannya lewat bahasa. Hubungan antara sebuah bahasa dan pikirannya sangat erat. Melalui bahasa, seseorang dapat menyampaikan apa yang diinginkan atau dimaksud dengan mudah. Manusia dapat juga menerima pengetahuan, informasi, berita, atau pesan-pesan melalui bahasa.

Tindak tutur merupakan hal yang dikaji dalam pragmatik. Mengujarkan sebuah tuturan tertentu dapat menghasilkan sebuah tindakan (mempengaruhi, menyuruh), di samping memang mengucapkan atau mengujarkan tuturan itu. Kegiatan melakukan tindakan mengujarkan tuturan itulah yang merupakan tindak tutur atau tindak ujar.

Dalam berkomunikasi tentunya penutur memiliki tujuan dan makna yang berbeda sesuai dengan konteks pada saat tuturan tersebut dituturkan oleh penutur. Artinya, setiap tuturan yang diucapkan oleh penutur merupakan tindak tutur dan setiap tuturan yang diucapkan penutur mengandung makna. Makna merupakan suatu maksud yang disampaikan oleh penutur dengan tujuan mitra tutur dapat memahami apa yang disampaikan oleh penutur tersebut. Wujud dari makna dapat dibagi menjadi dua, yaitu makna eksplisit dan makna implisit. Makna eksplisit merupakan makna yang informasinya sudah jelas dimengerti oleh mitra tutur. Adapun makna implisit merupakan makna yang harus diinterpretasikan oleh mitra tutur. Mitra tutur diharuskan memahami konteks dan kedaan, artinya makna implisit dalah makna yang tersirat dan tidak dinyatakan secara langsung. 
Mengingat bahasa sebagai alat komunikasi, realisasi penggunaan bahasa dalam masyarakat dapat terlihat pada media-media komunikasi, baik itu media elektronik seperti radio dan televisi maupun media cetak seperti koran dan majalah. Salah satu media elektronik yang paling banyak diminati oleh masyarakat adalah televisi.Sekarang ini televisi bukan lagi menjadi barang yang mewah melainkan sudah menjadi kebutuhan yang primer. Televisi digunakan sebagai hiburan dalam keluarga setelah melaksanakan aktivitas seharihari. Setiap keluarga biasanya memilih acara yang dianggap menarik. Acara televisi sekarang ini banyak dipenuhi oleh sinetron terutama pada malam hari. Salah satu tayangan televisi yang menjadi unggulan pada stasiun televisi swasta di Indonesia adalah sinetron komedi.

Sinetron komedi kebanyakan mengisahkan tentang kehidupan manusia dalam kehidupan sehari-hari dan disajikan dalam bentuk yang lucu atau humor. Salah satu program acara sinetron komedi yang menghibur, yang bermuatann budaya dan unik adalah "Tukang Ojek Pengkolan".

Pada penelitian kali ini penulis meneliti makna implisit dalam tindak tutur ilokusi yang tetrdapat pada sinetron Tukang Ojek Pengkolan. Penulis tertarik meneliti makna dalam tindak tutur karena tindak tutur dan makna saling berkaitan, karena pada saat berkomunnikasi penutur dan mitra tutur saling memahami konteks sehingga akan terhindar dari kesalahpahaman. Tidak hanya itu, di dalam berkomunikasi terkadang penutur menyampaikan tuturan secra tersirt maka mitra tutur mencoba menginterpretasikan tuturan tersebut. Begitupun pada penonton atau penikmat sinetron, penonton pun harus dapat menginterpretasi apa maksud yang disampaikan oleh penutur dan respon yang ditujukkan oleh mitra tutur.

Sinetron Tukang Ojek Pengkolan adalah sinetron bergenre drama komedi yang menarik untuk diteliti dan disimak. Dalam sinetron tersebut selain penutur menuturkan kalimat tuturan baik langsung maupun tidak langsung kepada lawan tutur. Penutur juga menggunakan tingkah laku yang konyol dalam berkomunikasi yang berwujud perintah, larangan, pernyataan, dan lain sebagainya, kepada lawan tutur yang bertujuan untuk menambah daya tarik kepada penonton.

Tetapi kebanyakan hanya menyukai karena percakapan dan tingkah laku yang dilakukan tokoh-tokoh bersifat lucu sehingga jarang sekali yang mendalami makna yang terdapat dalam percakapan tersebut, karena di dalam kelucuan tingkah laku dan percakapan yang lucu terdapat makna-makna yang perlu dipahami.

Dengan melakukan penelitian ini, penulis berharap agar penonton tidak mengalami kesalahpahaman atas komunikasi penutur dan mitra tutur. Karena dalam sebuah tuturan terkadang penutur menyampaikan sebuah makna secara tersirat.Berkaitan dengan latar belakang tersebut, penelitian ini mengambil percakapan dalam acara yang bertajuk sinetron komedi "Tukang Ojek Pengkolan" di stasiun televisi RCTI sebagai bahan penelitian. Fokus utama penelitian ini adalah untuk mendeskripsikan Tindak tutur ilokusi yang terjadi dalam Percakapan sinetron komedi "Tukang Ojek Pengkolan".

Berdasarkan latar belakang di atas, dirumuskan masalah penelitian sebagaii berikut: (1) bagaimanakah tindak tutur ilokusi yang terdapat pada percakapan sinetron "Tukang Ojek Pengkolan"?(2) Apafungsi tuturan ilokusi yang terdapat dalam percakapan sinetron "Tukang Ojek Pengkolan"? Sedangkan tujuan dari penelitian ini adalah (1) mendeskripsikan tindak tutur ilokusi yang terdapat pada percakapan sinetron "Tukang Ojek Pengkolan", (2) 
mengidentifikasi fungsi tuturan ilokusi yang terdapat dalam percakapan sinetron "Tukang Ojek Pengkolan".

\section{Metode}

Penelitian ini termasuk penelitin kualitaif dengan analisis kontekstual. Data yang diperoleh dalam penelitian ini adalah dari sumber lisan yaitu tuturan seluruh pemain yang mengandung tindak tutur ilokusi dalam sinetron komedi "Tukang Ojek Pengkolan", adapun sumber data dalam penelitian yaitu sinetron komedi "Tukang Ojek Pengkolan" yang ditayangkan pada tanggal 2-3 Mei 2017. Teknik pengumpulan data yang dipergunakan untuk pengumpulan data yaitu: teknik rekam, teknik simak, dan catat. Jadi setelah data penelitian didapatkan melalui teknik rekam, peneliti kemudian melakukan penyimakan dan setelah itu melakukan pencatatan terhadap data tersebut. Adapun proses pengumpulan ini dilakukan melalui beberapa langkah yakni:

1. peneliti mencari acara sinetron komedi "Tukang Ojek Pengkolan";

2. peneliti menonton sinetron "Tukang Ojek Pengkolan";

3. peneliti memilih tindak tutur yang ada dalam sinetron komedi "Tukang Ojek Pengkolan";

4. peneliti menganalisis data untuk mengetahui tindak tutur berdasarkan teori tindak tutur (lokusi, ilokusi, perlokusi) dikhususkan pada tindak tutur ilokusi: data yang dipilih, dikumpulkan berdasarkan masalah yang ditetapkan.

5. Pada saat penganalisisan data, dilakukan dengan penyelidikan data, pengklasifikasian data, serta pengkodean data.

Penelitian ini menggunakan pragmatik sebagai ancangannya. Penelitian bahasa yang menggunakan pragmatik sebagai ancangannya, selalu berkaitan dengan konteks, beitu pula penelitian ini. Konteks merupakan alat penentu dari luar bahasa, oleh karena itu, analisis dalam penelitian ini akan memakai metode padan pragmatis. Metode padan pragmatis adalah metode yang dipakai untuk mengkaji atau menentukan identitas satuan lingual tertentu dengan memakai alat penentu yang berada di luar bahasa.

\section{Hasil}

Dari hasil analisis yang telah dilakukan, dalam percakapan yang dilakukan oleh pemain sinetron Tukang Ojek Pengkolah (TOP) terdapat beberapa macam tuturan ilokusi, diantaranya tindak tutur representatif, direktif, dan ekspresif. Tindak tutur representatif terdapat menyatakan, melaporkan, dan mengeluh, tindak tutur direktif terdapat tindak tutur memberi nasihat, memesan, dan memohon. Pada tidak tutur komisif terdapat tindak tutur menawarkan. Serta pada tindak tutur ekspresif terdapat tindak tutur mengucapkan terima kasih dan meminta maaf.

\section{Pembahasan}

Mengujarkan sebuah tuturan merupakan hal penting di dalam kajian pragmatik. Mengujarkan sebuah tuturan tertentu untuk melakukan tindakan, di samping memang mengucapkan atau mengujarkan tuturan itu. Kegiatan melakukan tindakan mengujarkan tuturan itulah yang merupkaan tindak tutur atau tindak ujar. Bahkan dalam acara televisi 
pun tidak lepas dari tindakan mengujarkan tuturan seperti sinetron komedi "Tukang Ojek Pengkolan" yang ditayangkan di stasiun televisi RCTI.

Searle, 1969 (dalam Muhammad Rohmadi, 2004:29) Tindak tutur adalah produk atau hasil dari suatu kalimat dalam kondisi tertentu dan merupakan kesatuanterkecil dari komunikasi linguistik yang dapat berwujud pernyataan, pertanyaan,perintah atau yang lainnya. Searle mengatakan bahwa komunikasi bukan sekedar lambang, kata, atau kalimat, tetapi lebih tepat apabila disebut produk atau hasil dari lambang, kata, atau kalimat yang terwujud perilaku tindak tutur (the performance ofspeech acts).

Gunarwan (dalam Rustono 1999:33) menyatakan bahwa mengujarkan sebuah tuturan dapat dilihat sebagai melakukan tindakan (act), di samping memang mengucapkan (mengujarkan) tuturan itu. Aktivitas mengujarkan atau menuturkan tuturan dengan maksud tertentu itu merupakan tindak tutur atau tindak ujar (speech act).

Tindak ilokusi merupakan tindak tutur yang mengandung maksud dan daya tuturan. Tindak tutur tidak mudah diidentifikasi karena berkaitan dengan siapa bertutur kepada siapa, kapan, dan dimana tindak tutur itu dilakukan. Austin mengatakan bahwa tindak ilokusi adalah tindak melakukansesuatu (dalam Rustono, 1999:35). Tindak ilokusi merupakan tindak tuturyang mengandung maksud dan fungsi atau daya tuturan (Rustono 1999:37).

Tindak tutur yang terdapat dalam sinetron "Tukang Ojek Pengkolan" yang dilihat dari daya ilokusinya yaitu representatif, direktif, ekspresif, dan komisif.

\section{Tindak Tutur Representatif}

Tindak tutur representatif adalah tindak tutur yang mengikat penuturnya akan kebenaran atas apa yang diujarkannya. Jenis tindak tutur ini kadang-kadang disebut juga Tindak tutur asertif, Pada ilokusi ini terikat pada kebenaran proposisi yang diungkapkan, misalnya, menyatakan, mengusulkan, membual, mengeluh, mengemukakan pendapat, melaporkan.

\section{Tindak tutur representatif "menyatakan"}

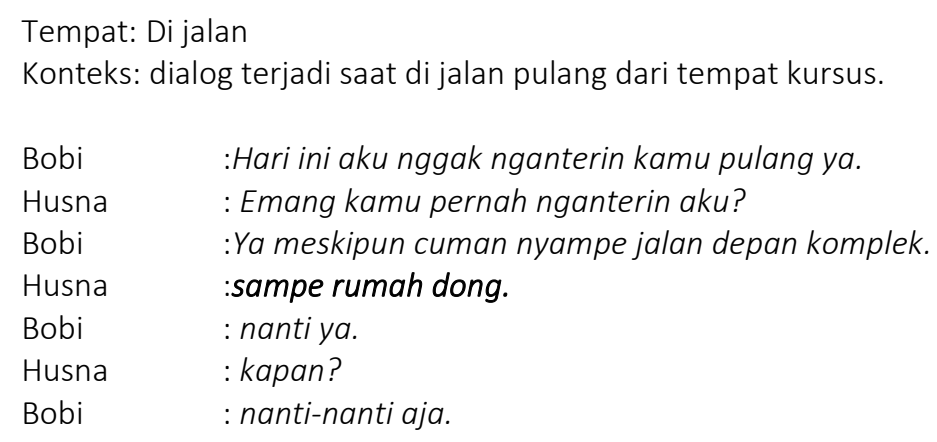

Pada tuturan tersebut menunjukkan tindak tutur representatif menyatakan keinginan. Penutur mengatakan kepada mitratutur "sampe rumah dong". Penutur tersebut bermaksud meminta pada mitra tutur untuk mengantarnya pulang sampai ke depan rumah.

\section{Tindak tutur representatif "melaporkan"}

Tempat: di depan rumah ratna dan juga tiur

Konteks: ojak baru saja mengantarkan tiur ke rumahnya, kmudian ratna keluar dan menyapa ojak

Lalu ratna keluar dari rumah

Ratna : bang

Ojak : na, abang abis nganterin mbak tiur beli gas 
Ratna

: Oh,, mampir yuk.

Kemudian ayah ratna keluar, dan ojak pun kaget.

Ojak : : Abang jalan ya.

Bpak : Kamu ngomong apa sama dia?

Percakapan tersebut merupakan representatif melaporkan. Penutur mengatakan kepada lawan tutur "na, abang abis nganterin mbak tiur beli gas", penutur bermaksud memberitahukan kepada mitra tutur bahwa penutur baru saja mengantarkan seseorang membeli gas.

\section{Tindak tutur representatif "mengeluh"}

Tempat: di kolam pemancingan

Konteks: Haji Murod, Pak Odi, dan Babeh Naim sedang memancing

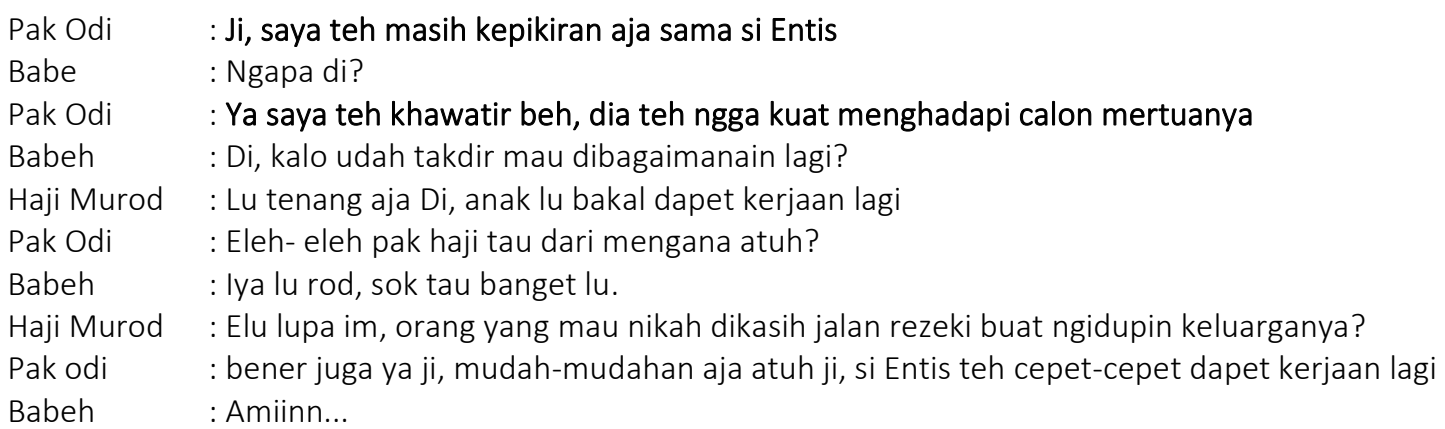

Pada kutipan percakapan di atas, jenis ilokusi yang digunakan adalah representatif "mengeluh". Pak Odi mengeluhkan keadaan anaknya yang baru saja keluar dari pekerjaannya sebagai mandor dan kembali lagi menjadi tukang ojek. la mengeluh kepada babeh Naim dan haji Murod.

\section{Tindak Tutur Direktif}

llokusi ini bertujuan mengasilkan suatu efek berupa tindakan yang dilakukan oleh petutur. Ilokusi ini misalnya, memesan, memerintah, memohon, menuntut, memberi nasihat.

\section{Tindak tutur direktif "memberi nasihat"}

Tempat: di gardu pinggir jalan

Konteks: Udin sedang duduk melamun di pinggir jalan, dan pak sofyan lewat saat berangkat ke kampus.

Kutipan 1

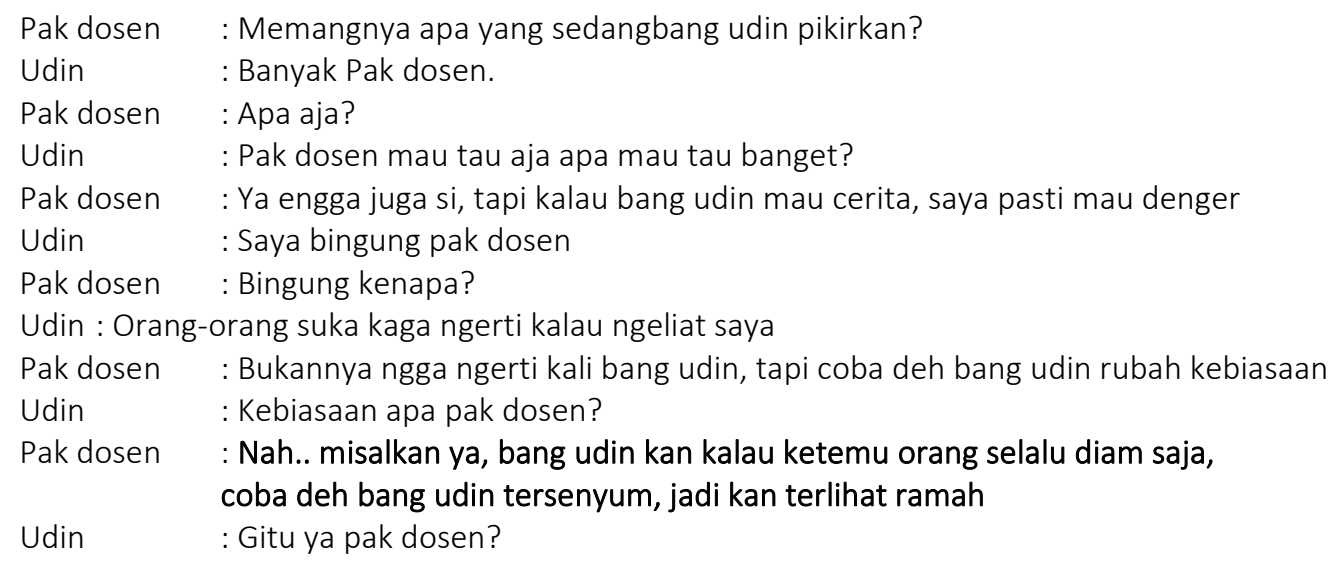


Pak dosen : : lya

Udin : :Terima kasih pak dosen, saya pulang dulu

Pada kutipan percakapan di atas termasuk tidak tutur ilokusi direktif. Subtindak tutur kutipan tersebut termasuk dalam "memberi nasihat". Pak sofyan atau pak dosen memberi nasihat kepada udin yang terlihat sedang banyak pikiran. Pak Sofyan memberi nasihat agar Udin selalu tersenyum saat bertemu dengan orang lain, karena selama ini udin selalu diam saat bertemu dengan orang.

Kutipan 2

Ojak : Budi, kalau dikasih tahu sama kakek dengerin, ngga usah takut

Budi : Emang om Ojak kagak takut?

Ojak : Ngapain mustitakut?

Tuturan pada kutipan di atas merupakan tindak tutur direktif. Subtindak tutur yang masuk dalam subtindak tutur "memberi nasihat". Ojak memberi nasihat kepada Budi agar selalu mendengarkan apa yang dikatakan oleh kakek budi, dan agar jangan takut. Karena kakek budi adalah orang yang keras.

\section{Tindak tutur direktif "memesan"}

Tempat: Warung Haji Sodik

Konteks: Saat Haji Sodik, mimin, dan udin sedang mengobrol tiba-tiba pak sofyan datang.

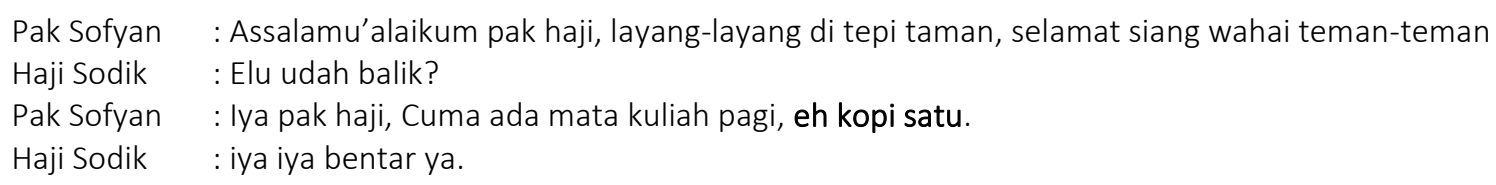

Tuturan pada kutipan percakapan di atas merupaan tindak tutur direktif. Subtindak tutur yang masuk dalam dalam subtindak tutur "memesan". Penanda lingual yang menyatakan "memesan" adalah "eh kopi satu". Tuturan tersebut terjadi di waruung haji Sodik yang berjualan kopi, teh, dan gorengan. pak sofyan bermaksud memesan kopi satu gelas kepada haji sodik.

\section{Tindak tutur direktif "memohon"}

Tempat: di jalan

Konteks: Saat sedang jalan ke tempat fotocopy, Bunga bertemu Bang Ojak yang merupakan tukang ojek.

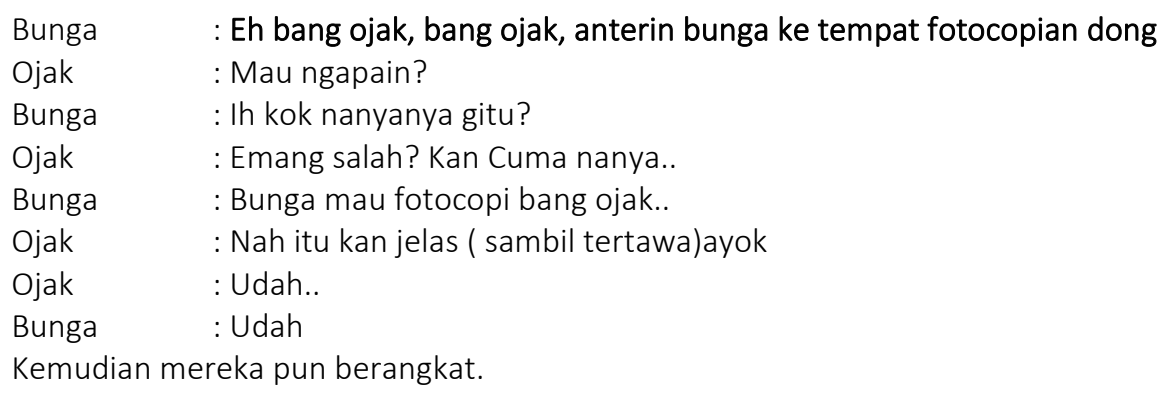

Pada kutipan percakapan di atas merupakan tindak tutur direktif. Tindak tutur direktif yang masuk dalam subtindak tutur "memohon". "anterin bunga ke tempat otocopian dong" menandakan bahwa tindak tutur tersebut menyatakan "memohon". Pada saat sedang jalan ke arah fotocopian, di tengah jalan Bunga bertemu dengan bang ojak. Bunga memohon kepada bang ojak untuk mengantarkannya ke tempat otocopian. 


\section{Tindak Tutur Komisif}

Pada ilokusi ini sedikit banyak terikat pada tindakan di masa depan, misalnya, menjanjikan, menawarkan, berkaul.

\section{Tindak tutur komisif "menawarkan"}

Tempat: di gardu pinggir jalan

Konteks: udin sedang duduk melamun di pinggir jalan, dan pak sofyan lewat saat berangkat ke kampus.

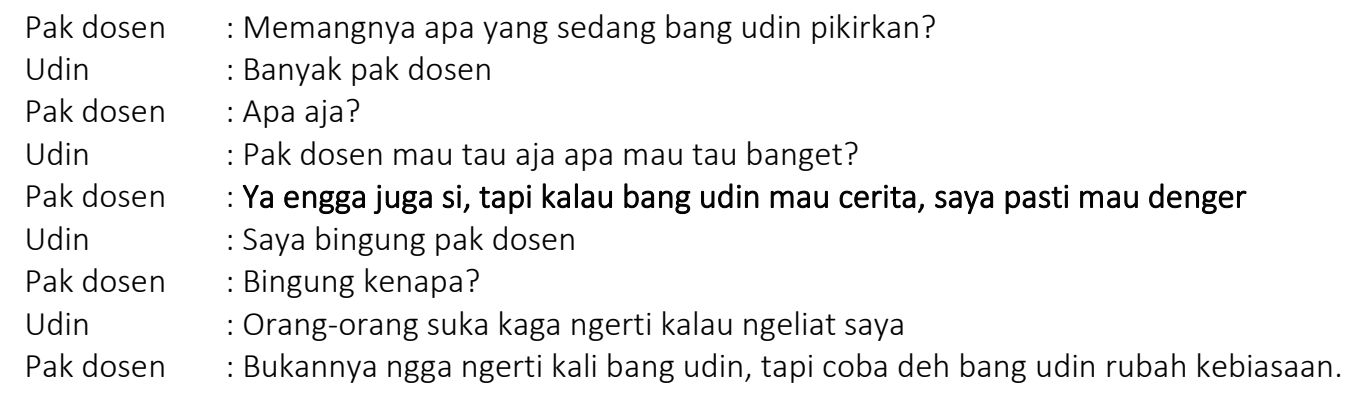

Pada kutipan percakapan di atas menunjukkan bahwa pak sofyan melakukan tindak tutur komisif menawarkan. Pak sofyan menawarkan kepada udin untuk menceritakan apa yang sedang dipikirkannya, karena udin terlihat melamun seperti banyak pikirn, dan pak sofyan siap untuk mendengarkan apa yang diceritakan oleh udin. Pada cuplikan percakapan di atas, "kalau bang udin mau cerita" merupakan penanda lingual subtindak tutur "menawarkan".

Tindak tutur komisif “menawarkan” juga terjadi pada kutipan percakapan berikut:

Tempat: di depam kontrakan Sarah

Konteks: Purnomo dan Sarah baru saja sampai di depan kontrakan Sarah

Sarah : terima kasih mas Purno

Purnomo : : Purnomo..., eh, Sar, besok dianterin lagi ngga?

Sarah : iya dong...

Purnomo : dongnya biasa aja dong...

Pada kutipan dialog di atas purnomo melakukan tindak tutur komisi "menawarkan", Purnomo menawarkan kepada Sarah untuk dapat mengantarkan sarah lagi dengan modus bertanya. Pada kalimat tanya " eh, Sar, besok dianterin lagi ngga?", kalimat tersebut purnomo bermaksud menawarkan.

\section{Tindak Tutur Ekspresif}

Fungsi ilokusi ini adalah mengungkapkan atau mengutarakan sikap psikologis penutur terhadap keadaan yang tersirat dalam ilokusi, misalnya, mengucapkan terima kasih, mengucapkan selamat, memberi maaf, mengecam, memuji, mengucapkan belasungkawa, dan sebagainya.

\section{Tindak tutur ekspresif "mengucapkan terima kasih"}

Tempat:Di pinggir jalan

Konteks: Nisa dan Bobi turun dari angkot

$\begin{array}{ll}\text { Nisa } & \text { : Kamu mau mampir dulu ngga? } \\ \text { Bobi } & \text { : Ngga usah deh aku langsung aja ya. } \\ \text { Nisa } & \text { : Yaudah makasih ya udah mau nganterin. } \\ \text { Bobi } & \text { : lya sama-sama. }\end{array}$


Pada tuturan tersebut, subtindak tutur yang digunakan adalah tindak tutur ekspresif "mengucapkan terima kasih. Pada kata "yaudah makasih" merupakan penanda lingual subtindak tutur "mengucapkan terima kasih. Pada tuturan tersebut nisa bermaksud berterima kasih karena Bobi telah mengantarkan Nisa pulang ke rumah, tetapi Bobi tidak mau mampir dan ingin langsung melanjutkan perjalanan pulang.

\section{Tindak tutur ekspresif "meminta maaf"}

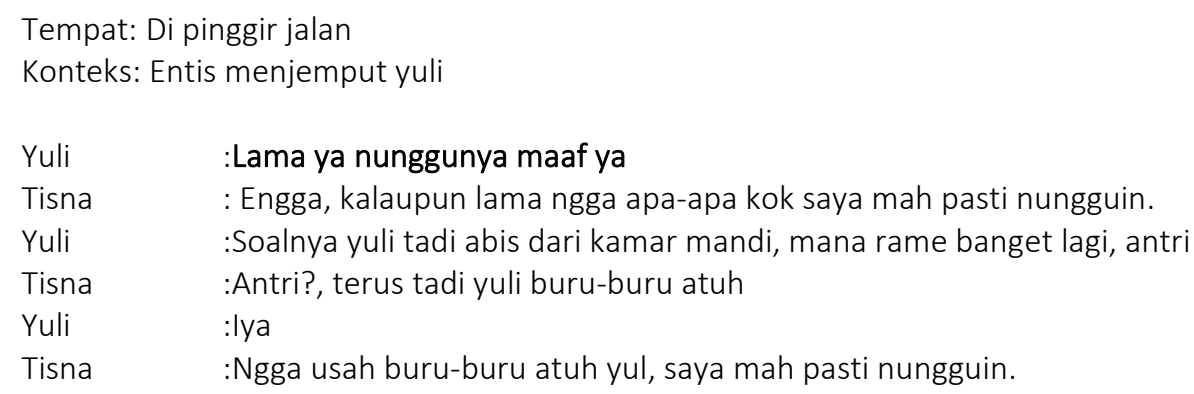

Pada cuplikan tuturan di atas termsuk tindak tutur ekspresif. Fungsi tindak tutur tersebut yang digunakan adalah fungsi "meminta maaf". Kata "maaf ya" merupakan penanda lingual subtindak tutur "meminta maaf". Pada uturan tersebut Yuli sebagai penumpang ojek kang Tisna, saat itu Tisna sudah menunggu lama di pinggir jalan, tetapi Yuli tidak datang-datang, ternyata ia selesai dari kamar mandi yang ramai sekali, sehingga saat akan mauk harus mengantri yang membuat Tisna lama menunggu di pinggir jalan.

\section{Kesimpulan}

Tindak tutur merupakan hal penting di dalam kajian pragmatik. Mengujarkan sebuah tuturan tertentu dapat dipandang sebagai melakukan tindakan (mempengaruhi, menyuruh), di samping memang mengucapkan atau mengujarkan tuturan itu. Kegiatan melakukan tindakan mengujarkan tuturan itulah yang merupakan tindak tutur atau tindak ujar.Bentuk tuturan dalam sinetron Tukang Ojek Pengkolan sama seperti perckapan pada umumnya yang meliputi tindak tutur representatif, direktif, komisi, dan ekspresif. Di dalam sinetron Tukang Ojek Pengkolan terdapat tidak tutur ilokusi representatif yang digunakan untuk menyatakan, melaporkan, dan mengeluh. Tindak tutur ilokusi direktif digunakan dalam konteks menasihati memesan, dan memohon. Tindak tutur ilokusi komisif digunakan dalam konteks menawarkan. Tindak tutur ilokusi ekspresif digunakan dalam konteks mengucapkan terima kasih dan meminta maaf.

\section{Ucapan Terima Kasih}

[].

\section{Referensi}

Gunarwan, A. (1994). Kesantunan Negatif di Kalangan Dwibahasawan Indonesia Jawa di Jakarta: Kajian Sosiopragmatik. PELLBA 7. Jakarta: Pusat Kajian Bahasa dan Budaya Unika Atmajaya.

Leech, G. (1993). Prinsip-prinsip Pragmatik, (Terjemahan M.D.D Oka). Jakarta: Universitas Indonesia 
Prasetyo, D. (2009). Tindak Tutur Ilokusi Dalam Sinetron Komedi Cagur Naik Bajaj Di Stasiun Televisi ANTV (Skripsi). Surakarta: Universitas Sebelas Maret.

Rustono. (1999). Pokok-pokok Pragmatik. Semarang: CV IKIP Semarang Press.

Subroto, E. (1992). Pengantar Metode Penelitian Linguistik Struktural. Surakarta: UNS Press Sudaryanto. (1993). Metode dan Aneka Teknik Analisis Bahasa. Yogyakarta: Duta Wacana University Press.

Yule, G. (2006). Pragmatik. Yogyakarta: Pustaka Pelajar 